ARTICLE

DOI: $10.1057 /$ s41599-018-0082-z

\title{
Edgar Allan Poe in Transylvania: Poe's short stories and gothic elements in nineteenth century Romanian literature
}

\author{
Lucian-Vasile Szabo $^{1} \&$ Marius-Mircea Crișan ${ }^{1}$
}

\begin{abstract}
This study presents a new integrative image of the reception of Edgar Allan Poe in Romanian literature, especially in the second part of the nineteenth century, and offers new perspectives on translations of his work into Romanian. Although his writings were eventually translated into Romanian, his work had become known earlier through French translations by Charles Baudelaire. Poe's work, translated from French, was published in various Romanian language publications during the second half of the nineteenth century. At the beginning of the 20th century a great number of direct translations into Romanian became available, many of these being found in Transylvania and the Banat. This paper discusses the re-analysis of these Romanian translations, the plurality of which suggests an on-going interest in Poe's literature. The paper specifically focuses on the particular conditions of translations published in areas in East-Central Europe that were inhabited by Romanians. The study also approaches the influence of Poe on Romanian literature by highlighting new critical perspectives on Romanian writers' interests in the American author's works.
\end{abstract}

\footnotetext{
${ }^{1}$ West University of Timisoara, Timisoara, Timis, Romania. Correspondence and requests for materials should be addressed to M.-M.C. (email: marius_crisan@yahoo.com)
} 
Edgar Allan Poe in Romanian cultural space: the nineteenth century and the beginning of the twentieth century

- dgar Allan Poe's writings were translated into Romanian and became known relatively early, but not through direct translation, but by means of Charles Baudelaire's French translations. Poe's work, translated from French, was published in various Romanian language publications during the second half of the nineteenth century. At the beginning of the $20^{\text {th }}$ century a great number of direct translations into Romanian became available, many of these being found in Transylvania and the Banat. Until 1918, when they united with Romania, these two regions had belonged to the Austro-Hungarian Empire. Unlike Bucharest and Jassy, the most important towns in the United Principalities (Wallachia and Moldavia), namely the future Kingdom of Romania (1881), where culture was absorbed by using French as a lingua franca, the language with the strongest ascendant in Transylvania and the Banat was German. Thus, Romantic and Gothic literatures had a tradition in the latter regions, as, from a cultural point of view, Transylvania and the Banat identified with Central Europe. Edgar Allan Poe was preoccupied with the Viennese sphere of influence, a number of his themes and characters (of Gothic and Fantasy nature) originating from this region. His short stories outline a particular image of East-Central Europe, depicted as a haunted mythical remote space (Szabo and Crișan, 2017, p 64).

This study intends to offer a new integrative image of the reception of E. A. Poe in Romanian literature, especially in the second part of the nineteenth century, offering new perspectives on the translations into Romanian. The re-analysis of several details about the translations from Poe also points to the plurality of variants, which suggests a constant interest in Poe's literature. Special attention is paid to some particular conditions of translations published in different places in East-Central Europe inhabited by Romanians. The study also approaches the influence of Poe on Romanian literature, by bringing new critical perspectives on the interest of Romanian writers in the American author.

The American writer made no reference to Romania in any of his writings, notes included. However, one can trace an indirect reference to Romania in Pinakidia 57, but Burton R. Pollin believes it to be a confusion. Poe was discussing the universal motive of Cinderella, quoting a certain "Schottky". He writes: "Schottky found it among the Servian fables" (Poe, 1985, p 41), and Pollin's comment is: "There is a probable error in the name "Schottky". Cox records a Wallachian version in Arthur and Albert Schott, Walachische Märchen (Schott, 1845), p 77, 117 (Wallachia, an old name for a region of Romania, may be considered as tantamount to "Serbia"). There is no doubt about the Serbian versions of Cinderella, as shown in William Denton, Papalluga, or the Golden Slipper (London, 1874, pp 59-66, given by Cox, p 14) and Vuk Karadžić, Serbian Folk-Tales (Vuk Karajick, 1854), pp 131-133, p 169." (Poe, 1985, p 43). Walachische Märchen/Basme valahe (Wallachian Tales) is a collection compiled around the Oravița area, thus the probable source of Poe's Serbian "contagion". According to Eliana Popeți, the Schott Brothers' collection of fairytales constructs a Romanian identity from a German perspective (Popeți, 2013, p 457). Arthur Schott, whose perception of Romanian folklore is approached by Otilia Hedeșan (Hedeșan, 2000, p 144, p 304) had spent five years (1836-1841) in the Banat (by the border on today's Serbia), and later on went to the United States.

The Schott brothers' collection of tales also comprises Das Mädchen im goldenen Garten / Fata din grădina de aur (The Girl in the Golden Garden), used by the Romanian national poet Mihai Eminescu when writing his masterpiece, Luceafărul (The Evening Star). Eminescu became familiar with the tale through Richard
Kunisch (the diplomat), who had reproduced the summary of this tale in his book. It is important to observe that two of the classics of Romanian literature paid special attention to the literary work of Edgar Allan Poe: both Mihai Eminescu and his contemporary, Ion Luca Caragiale, the greatest Romanian playwright, translated short stories from the American author.

\section{Poe and the Central Europeans}

E. A. Poe found various sources of inspiration in the classic works of literature. The European cultural heritage constituted an important source, particularly at the start of his literary activities. Not only had Poe a thorough knowledge of the most important literary texts, but he also had a profound understanding of their meanings. He had a good command of French and Latin, which explained his interest in both contemporary works (in English and French) and classical ones.

Poe also was a proficient reader of scientific treaties, and some of his stories would be influenced by topics presented in the journals of the time, as during his life the number of publications available would be on the rise. The journals were filled with bizarre stories, some of them cruel and unusual, thus giving Poe the opportunity to reinterpret them in a Gothic manner. This was the context in which he named his first volume Tales of the Grotesque and Arabesque.

Liviu Cotrău, Poe's Romanian editor, used an excessive amount of arguments to show that the Romanian translation should be Povești groteşti şi arăbeşti ("Grotesque and Arabian Tales"). Previously, it had been Poveşti groteşti şi extraordinare ("Grotesque and Extraordinary Tales"). One believes that the American author gave specific meanings to the two terms he used to characterize the stories comprised in the volume. Following up on suggestions made by several of Poe's commentators, Liviu Cotrău explains that: "the arabesque-a decorative design consisting of an intricate network of lines - originates from the Grotesque drawings reproduced by Rafael and his disciples in the Vatican Loggia. In the Italian Renaissance, the arabesque is replaced by the classic Gothic style, but the original Arabian term is kept, while the Saracen (or Arab) art would become known as Moorish art. The arabesque would make reference, exclusively, to the style rooted in the classic grotesque of the Roman period" (Cotrău, 1990, p 688). The latter phrase alludes to the use of the word grotesque in connection with the grottos, a term used to make reference to the cave-like chambers discovered in the Roman ruins of Rome and Pompeii. The arabesque is also a ballet figure that highlights the symmetry and suppleness of the artists. The influence of E. A. Poe on Romanian literature, is approached in the volume The Scythe of Time (Cotrău, 1999).

When mentioning Poe's literary incursions into Central Europe, one has to notice that the writer created a sort of fictional synthesis of this space. Although there are numerous references to the Hungarian space, they are frequently set in a German context, some of them being made to the town of Pressburg (in German) or Pozsonyi (in Hungarian), the old name of Bratislava-today the capital city of Slovakia-the capital city of Hungary in the past (during more than two centuries, from 1541 to 1784). The construction of Pressburg in Poe's work is discussed in Lucian-Vasile Szabo and Marius-Mircea Crişan's essay, "'Bloodthirsty and remorseless fangs': Representation of East-Central Europe in Edgar Allan Poe's Gothic short stories". The same essay examines the Gothic dimension of Poe's imagined Hungary, as described in Metzengerstein, a short story which has several Gothic elements that anticipate Bram Stoker's Transylvania. The castle described in this short story has several characteristics that will be developed by Bram Stoker in the construction of Castle Dracula (Szabo and Crişan, 2017). According to some literary critics, the plot of 
Metzengerstein is set in Transylvania, which, at that time, belonged to the Hapsburg Empire (Benton, 1996, p 113; Mabbott, Collected Works of Edgar Allan Poe, 1978, p 206).

\section{Baudelaire as a mediator}

In the second part of the nineteenth century, Poe would become extremely popular in the Romanian cultural space, translations of his works being quite frequent-both among the Romanians of Wallachia and Moldavia (the United Principalities) and among those from Transylvania and the Banat.

"The French connection" will always be invoked with regard to the immense gateway it constituted for Poe's work to reach both the world and the Romanian culture. This matter has been scrutinized constantly by the exegetes (Cotrău, 2014). In 1971, a well renowned Americanist underlined the complexity of this topic in the preface of a Romanian edition of the American writer's literary theory works: "The American critics or writers do not hide their surprise concerning Poe's European fate. We were facing a myth, the spreading of which-to the modern French culture, and later on, to other European countries - could be explained by a more or less arbitrary train of events." (Călinescu, $1971, \mathrm{p}$ 5). There are two reasons for this controversy to be mentioned. The first one would be the fact that Poe's writing was, supposedly, lacking in magnitude, as many fragments of his work had stylistic problems. The second controversy reason was the fact the translation itself had mystifying tendencies, Baudelaire and other French men of letters falling under the suspicion of not having completely understood the meaning of the original text. This issue had also been mentioned by the journalist Constantin Noica in 1929: "America is to us, meaning from Baudelaire-who used to protest against the fact that Poe had not been understood there-to the last of the European snobs (yourself and I), the country of platitude imposed by materialism and of soul bearing demanded by an external and exclusive gesticulation." (Noica, 1994, p 388).

The interest in Poe's writings was high, especially for the mystery and terror prose. The first work translated into Romanian was The Pit and the Pendulum, a work in which the Gothic genre is reassessed and modernized by introducing abysmal psychology elements. It was published in the form of fiction in installments under the title Puțul și pendula (in Romanian). One version was anonymously reproduced in the Independența (The Independece), IV, nr. 17-21, in 1861. This translation did not have an immediate effect in Romanian literature, as the publication Independența ("The Independence") was one without impact. Subsequently, as the number of translations from E. A. Poe increases, we can observe Poe's influence on some important Romanian writers (Carlson, 1999). Other variants followed, some signed by their translators, some anonymous, The Pit and the Pendulum being one of Poe's best known works to the Romanian speaking public. However, the translation of reference remains that of Ion Vinea (published in 1965), an important poet, but also writer of some less known fantastic-realist fiction. One's attention is drawn by the fact that some great Romanian writers were interested in translating Poe, amongst them being I. L. Caragiale, Alexandru Macedonski and Mihai Eminescu.

When mentioning Caragiale's translation of some of Poe's short stories (namely, Ion Luca Caragiale, as his less known son, Luca Ion Caragiale, also proved his talent as a translator by rendering a rather skillful version of The Raven!), the scholar Liviu Cotrău notes a first contribution, The Devil in the Belfry, translated into Romanian as Dracul în clopotniță and published in installments in Timpul ("The Time"), year I, nr. 64-66, 1876 (Cotrău, 1990, p 672). The following one, two years later, published in Timpul as well, was Caragiale's translation of A Tale of Jerusalem, rendered into Romanian as $O$ intâmplare la Ierusalim. The third of Caragiale's translations was the tale "The Masque of the Red Death", title rendered by the Romanian author as Masca ("The Mask") (Epoca literară ("The Literary Epoch"), I, nr. 1, 1896). Moreover, the translator would make some abbreviations to the text (Streinu, 1935). The scholars who studied Caragiale's work did not initially note this translation being published in Epoca (The Epoch), but did mention that a text by Caragiale had been published in 1898 in Calendarul Dacia ("The Dacia Calendar"). They also mentioned a low quality anonymous version that had been published in 1885, in the journal Tezaurul familiei ("The Family Treasure") (Zarifopol, 1931, p 640). Poe's "The Masque of the Red Death" was quite successful with the Romanian speaking audience, and there were several good translations of it. The text of reference is again Ion Vinea's version, having the more adequate title Masca morții roşii (Poe, 1990). "The Masque of the Red Death" has several versions of translation (Hăisan (2014)). Caragiale had translated Poe by using the French intermediaries, as he was proficient in this language. Charles Baudelaire's translation would be used. In 1878, in the newspaper Timpul (The Time) once more, one could find the translation of The System of Dr. Tarr and Professor Fether, rendered into Romanian as Sistema doctorului Catran si a Profesorului Pană. The influence on I. L. Caragiale's original prose is evident: "In the case of Caragiale... readers will easily recognize the melancholy tone and dark atmospherics that characterize so much Poe's poetry and fiction" (Carlson, 1999). We are still speaking about the fascination for the macabre, extreme psychic states and oneiric visions, accurate appreciations for the fantastic prose of Caragiale and other Romanian authors, inclusively Mihai Eminescu.

\section{Terrible delicacies}

One finds a certain similarity between Poe and Caragiale when analyzing two works that include the topic of cannibalism. In Poe's case, it is the novel The Narrative of Arthur Gordon Pym that describes a situation where cannibalism takes place. The survivors of some difficult trials, namely a mutiny and a storm that would wreck the ship-leaving the few surviving persons without any resources-would have to cast lots in order to choose the person to die in order for the other ones to stay alive. A certain Parker would be sacrificed, the scene being highly tragic. One can feel despair echoing from each of Poe's words: "I must not dwell upon the fearful repast which immediately ensued. Such things may be imagined, but words have no power to impress the mind with the exquisite horror of their reality. Let it suffice to say that, having in some measure appeased the raging thirst which consumed us by the blood of the victim, and having by common consent taken off the hands, feet, and head, throwing them together with the entrails, into the sea, we devoured the rest of the body, piecemeal, during the four ever memorable days of the seventeenth, eighteenth, nineteenth, and twentieth of the month" (Poe, 2005, p 653). As for Caragiale's story, the Turk Iusuf takes delight in eating the appetizing pastrami made from Aron the Jew's father, without being aware that he actually tastes human flesh. The approach is different. In Poe's story the context is tragic due to the need of survival. In Caragiale's short story the reason for (accidentally) eating human flesh is a caprice, the need to satisfy an appetite. This is written with a comic note, as the short story Pastramă trufanda is constructed by accumulating facts meant to build its anecdotal character. It is a case of involuntary cannibalism, as Iusuf did not know the delicacies he found in a sack were prepared out of human flesh (Szabo, 2014b). 


\section{Black cats and ragged mountains}

Morella has at least seven versions in Romanian, one of them translated by Mihai Eminescu and Veronica Micle. A version of this translation was published in Curierul de Iași, IX, 1876, nr. 111; at that time Emisecu was the editor of that publication. The source was again the French version by Baudelaire. The process of translating this story reflects a phase of the love relationship between Mihai Eminescu and Veronica Micle (Ioana Pârvulescu 2007). However, Liviu Cotrău, the editor of Poe's work in Romanian, questions the collaboration between the two poets on this translation (Poe, 1990, pp 527-531). According to D. Vatamaniuc, the facts related in the story corresponded to the phase of the relationship between Mihai Eminescu and Veronica Micle in the period 1875-1876 (Vatamaniuc, 1985, p 191). In this context, we can observe an influence of Edgar Allan Poe on Mihai Eminescu's fantastic writing, more precisely on the text Archaeus, which is, according to Vatamaniuc a literary answer to Edgar Allan Poe's Morella (Vatamaniuc, 1985, p 193). The reference translated text of Morella is the one by Mihu Dragomir and Constantin Vonghizas (Poe, 1968).

The Tell-Tale Heart is another very popular tale in Romania, having eight translated versions. The first translation had Baudelaire's French version as a source text, and was entitled Inima destăinuitoare in Romanian. The translation belonged to $\mathrm{B}$. Florescu and appeared in the Telegraful ("The Telegraph"), V, nr. 853,1875 . Later on, the title was changed to Inima trădătoare ("Treacherous Heart"), and this title was born by five of the versions. Ion Vinea went for Inima care-şi spune taina ("The Heart that Tells Its Secret"), while L. Cotrău, somewhat surprisingly, returned to the title Inima destăinuitoare. The Black Cat, one of Poe's pièces de résistance, has six known versions, the Romanian title being Pisica neagră. Surprisingly, two of these versions bear the title Cotoiul negru (The Black Tomcat). A Tale of the Ragged Mountains has five translations into Romanian, the first one being $O$ istorisire din "Ragged Mountains", a fairly accurate translation published in the Gazeta Transilvaniei (The Transylvanian Gazette), LXI, nr. 82-84, 1898. Other versions include: Suvenirurile d-lui Bedloe (Mister Bedloe's Memories), followed by În munți (In the Mountains), and then Petru Solomon's O întâlnire în Munții Colțoşi (A Meeting in the Ragged Mountains). L. Cotrău, who put all these versions together, favored the title Poveste din Munții Colțuroşi (A Tale of the Ragged Mountains). This version is faithful to the source text, the translator and the editor having the fidelity principle in mind. Interestingly, a complicated and playful title such as The System of Dr Tarr and Professor Feather did not have any special or surprising variations in any of its five Romanian versions. Tarr is translated as Catran and Gudron, and Feather as Pană or Puf. One could somewhat get a feel of Nathaniel Hawthorne's influence, considering his tale Feathertop, meaning scarecrow.

For The Facts in the Case of M. Valdemar L. Cotrău identified seven Romanian versions. The eighth one belongs to Cotrău himself. Charles Baudelaire had given his version the title Mort ou vivant? Cas de M. Valdemar. It is important to underline this fact because it suggests that the Romanian translators started using the original text in English, thus abandoning intermediary French texts. Bonifaciu Florescu, one of the first to have translated E. A. Poe into Romanian, chose the title Adevărul asupra cazului d-lui Valdemar (The Truth on Mister Valdemar' Case), published in the Povestitorul (The Story Teller), I, nr. 2, 1876. The title is kept, for the most part, for other versions (Szabo, 2013, p 39). The title Faptele in cazul domnului Valdemar, faithfully rendering the original one, would be used by Mihu Dragomir and Constantin Vonghizas, and later on by Liviu Cotrău. He would even specify that: "The growing interest in Mesmer's doctrine makes The Facts in the Case of M. Valdemar, translated under various titles, the most popular short story" (Cotrău, 1987, p 28), of those translated into Romanian, of course. As shown, A Tale of the Ragged Mountains did catch the attention of the public, whereas Mesmeric Revelation was ignored.

Hop-Frog, one of Poe's last stories, was translated into Romanian in 1891 and published in the Naţiunea ("The Nation"), $\mathrm{X}, \mathrm{nr} .2527-2533,1891$. The title remained unchanged, as it did in Charles Baudelaire version. In 1909-in Gazeta Transilvaniei ("The Transylvanian Gazette")-one encounters a title containing an explanation: Hop-Frog (Broscuța țopăitoare/The Leaping Frog). In 1915 Gazeta Transilvaniei (The Transylvanian Gazette) published a version entitled Eight Orangutans. Ion Vinea's post World War II version (re-edited several times) was Hopa-Hop sau opt urangutani înlănțuiți (Hopa-Hop or Eight Chained Orangutans). Liviu Cotrău translated the text again, choosing HopaBroscuță (Hop-Frog) as a title and thus remaining faithful to E. A. Poe's text.

\section{Poe in Transylvania and in the Banat}

Poe's Romanian language "adventure" can be traced according to the titles given to the translations that were published. As anticipated earlier, one could witness great diversity in this respect. Some works in prose received great attention from the Romanian men of letters, several versions being translated and printed. Some of these, even if of great value, were ignored. Several versions of the American writer's pieces of fiction appeared (in the second half of the nineteenth century and the beginning of the twentieth century) in most Romanian language publications, this being a phenomenon worthy of interest. In the Old Kingdom of Romania, one could find them in publications from Bucharest, Jassy or Craiova. The interest for these texts ran high in the Transylvanian space as well, since we could find them in various publications in Brașov (Gazeta Transilvaniei, "The Transylvanian Gazette"), Sibiu (Tribuna, "The Tribune"), Arad (Tribuna poporului, "The People's Tribune", renamed Tribuna, "The Tribune" since 1904).

The journals in the Banat were also active (even more so than the ones in Moldavia), and Poe's works were found in Timişoara (Dreptatea, "Justice"), Lugoj (Drapelul /"The Flag") and Oravița (Progresul, "Progress"). This literary geography chapter was made complete by the Romanian language publications from Budapest (Lupta, "The Battle" and Foaia ilustrată, "The Illustrated News", for instance), at the beginning of the nineteenth century.

Sofia Nădejde was an important translator of Edgar Allan Poe's work. She was the wife of Ioan Nădejde, well known leader holding socialist views and an important journalist of the time. Sofia Nădejde also wrote fiction and advocated women's rights in Romania. Although she lived in Jassy and Bucharest, Sofia Nădejde's favorite journal for publishing her translations was Progresul (Progress) of Oravița. It was also there that her version of A Tale of the Ragged Mountains, entitled simply In munți ("Up in the Mountains"), would be published. The daily newspaper Dreptatea ("Justice"), appearing at the end of the nineteenth century in Timissoara, was the place where the mysterious translator Byr published his many renderings of Poe's works. Some of the works he translated were The Murders of the Rue Morgue, The Tell-Tale Heart or The Purloined Letter. Concerning the latter one, M. Zaciu specifies that one of the first translations into Romanian is thought to have appeared in 1898 or 1899 in Craiova, Șt. P. being the translator (Zaciu, 1983, p 146). The first Romanian translation was, however, published in 1895, in Dreptatea (Justice). The Craiova version was from 1987, when E. A. Poe's book Scrisoarea furată, Ruina casei Usher, Pisica neagră, Portretul oval și alte povestiri extraordinare (The Purloined Letter, The Fall of the House of Usher, The Black Cat, The Oval Portrait 
and other extraordinary tales) was edited by Ignat Samitca. Subsequently, several versions were published, the reference text being Ion Vinea's translation (Poe, 1965). In the period following 1950s, Poe had a special situation in Romania, being perceived as an author of science fiction prose (Olos, 2010).

Edgar Allan Poe's image took shape in Romanian readers' minds through the translations of his works, which were published in all of the Romanian provinces. The Gothic, mystery and horror were amongst the favorite genres, and Poe had an influence over some of the most important Romanian writers.

\section{Data availability}

Data sharing is not applicable to this article as no datasets were generated or analyzed during the current study.

Received: 27 July 2017 Accepted: 21 February 2018

Published online: 20 March 2018

\section{References}

Aderman RM (1970) Poe in Rumania: a bibliography Poe Newsl 3(1):19-20

Benton RP (1996) The Tales: 1831-1835. In: Carlson EW (ed) A companion to Poe studies. Greenwood Press, Westport, Connecticut, London, pp 110-128

Vuk Karajick (1854) Serbian Folk-Tales. Berlin

Carlson TC (1999) Poe in Romania. In: Lois DV (ed) Poe abroad: influence, reputation, affinities. University of Iowa Press, pp 75-81

Călinescu M (1971) Eseurile despre poezie ale lui Edgar Poe. In: Poe EA (ed) Principiul poetic. Univers, Bucharest

Cotrău L (1987) Prefață. In: Poe EA (ed) Annabel Lee şi alte poeme. Univers, Bucharest

Cotrău L (1990) Prefață. In: Poe EA (ed) Prăbuşirea Casei Usher, Editura Univers, București

Cotrău L (1999) The scythe of time. Editura Napoca Star, Cluj-Napoca

Cotrău L (2014) (Un)Masking the red death in Romanian translations. In: Esplin E, Gato MV (eds) Translated Poe. Lehigh University Press, Bethlehem, PA, pp $75-86$

Durán-Merk A, Merk S (2014) Arthur Schott: a true renaissance man in the Americas (2014) INDIANA 31, Ibero-Amerikanisches Institut, Stiftung Preußischer Kulturbesitz. p 161-191, http://www.iai.spk-berlin.de/fileadmin/ dokumentenbibliothek/Indiana/Indiana_31/IND_31_2014_161-191_DuranMerk.pdf

Hăisan D (2014) (Un)Masking the red death in Romanian translations. In: Esplin E, de Gato M (eds) Translated Poe. Lehigh University Press, Bethlehem, PA, pp 231-240

Hedeșan O (2000) Pentru o mitologie difuză. Marineasa, Timișoara

Noica C (1994) Semnelei Minervei Publicistica I. Humanitas, Bucharest

Olos A (2010) Premises for the reception of Edgar Allan Poe's work in Romania at the bicentenary of his birth. Edgar Allan Poe Rev 11(2):9-20

Pârvulescu I (2007) Ce traduce Veronica Micle. România literară. 29(14). http:// www.romlit.ro/ce_traduce_veronica_micle. Accessed 1 Dec 2017

Poe EA (1978) Collected works of Edgar Allan Poe, Tales and Setches1843-1849. The Belknap Press of Harvard University Press, Cambridge, Massachusetts London, England, Edited by Thomass Ollive Mabbott
The Collected Writings of Edgar Allan Poe-Vol II: The Brevities,1985, The Gordian Press, New York

Poe EA (1965) Prăbuşirea Casei Usher. Editura pentru literatură, Bucharest Poe EA (1968) Scrieri alese. Editura pentru literatură universală, Bucharest Poe EA (1985) The Collected Writings. The Gordian Press, New York Poe EA (1990) Prăbuşirea Casei Usher. Editura Univers, Bucharest

The Collected Tales and Poems of Edgar Allan Poe 2004, Wordsworth Editions, London

Poe EA (2005) Misterul lui Marie Rogêt și alte povestiri. Editura Polirom, Iași

Popeți E-A (2013) Prima culegere de basme populare românești: identitate și alteritate. In: Botoșineanu L, Ichim O, Maticiuc C, Moscal D, Tamba E(eds) Tradiție/inovație-identitate/alteritate: paradigme în evoluțoa limbii și culturii române. Editura Universității “Alexandru Ioan Cuza", Iași

Streinu V (1935) Edgar Poe si scriitorii români. Rev Fundatiilor Regal 2(6):620-641

Schott A, Albert S (eds) (1845) Walachische Märchen. J. G. Cotta, Stuttgart

Szabo L-V (2013) The facts in the Case E A Poe. Fantasy, real life, science fiction, journalism. LAP Lambert Academic Publishing, Saarbrücken

Szabo L-V (2014a) E. A. POE: Romantism, modernism, postmodernism. Implicaţii jurnalistice, fantastice şi science fiction. Editura Tritonic, București

Szabo L-V (2014b) E. A. Poe, I. L. Caragiale, philosophy, and wine. Transylv Rev 3:52-64. (23)

Szabo L-V, Crișan M-M (2017). Bloodthirsty and remorseless fangs: Representation of East-Central Europe in Edgar Allan Poe's Gothic short stories. In: Marius-Mircea C (ed) Dracula: an international perspective. Palgrave Gothic, Cham, pp 53-68

Vatamaniuc D (1985) Publicistica lui Eminescu. Junimea, Iași

Zaciu M (1983) Viaticum. Cartea Românească, Bucharest

Zarifopol P (1931) Note și variante. In: Caragiale IL. Opere, Bucharest

\section{Additional information}

Competing interests: The authors declare no competing financial interests.

Reprints and permission information is available online at http://www.nature.com/ reprints

Publisher's note: Springer Nature remains neutral with regard to jurisdictional claims in published maps and institutional affiliations.

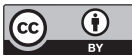

Open Access This article is licensed under a Creative Commons Attribution 4.0 International License, which permits use, sharing, adaptation, distribution and reproduction in any medium or format, as long as you give appropriate credit to the original author(s) and the source, provide a link to the Creative Commons license, and indicate if changes were made. The images or other third party material in this article are included in the article's Creative Commons license, unless indicated otherwise in a credit line to the material. If material is not included in the article's Creative Commons license and your intended use is not permitted by statutory regulation or exceeds the permitted use, you will need to obtain permission directly from the copyright holder. To view a copy of this license, visit http://creativecommons.org/ licenses/by/4.0/.

(C) The Author(s) 2018 